IZA DP No. 4218

Parental Education and Wages:

Evidence from China

Yuanyuan Chen

Shuaizhang Feng

June 2009 


\title{
Parental Education and Wages: Evidence from China
}

\author{
Yuanyuan Chen \\ Shanghai University of Finance and Economics \\ Shuaizhang Feng \\ Princeton University \\ and IZA
}

Discussion Paper No. 4218

June 2009

IZA

P.O. Box 7240

53072 Bonn

Germany

Phone: +49-228-3894-0

Fax: +49-228-3894-180

E-mail: iza@iza.org

Any opinions expressed here are those of the author(s) and not those of IZA. Research published in this series may include views on policy, but the institute itself takes no institutional policy positions.

The Institute for the Study of Labor (IZA) in Bonn is a local and virtual international research center and a place of communication between science, politics and business. IZA is an independent nonprofit organization supported by Deutsche Post Foundation. The center is associated with the University of Bonn and offers a stimulating research environment through its international network, workshops and conferences, data service, project support, research visits and doctoral program. IZA engages in (i) original and internationally competitive research in all fields of labor economics, (ii) development of policy concepts, and (iii) dissemination of research results and concepts to the interested public.

IZA Discussion Papers often represent preliminary work and are circulated to encourage discussion. Citation of such a paper should account for its provisional character. A revised version may be available directly from the author. 
IZA Discussion Paper No. 4218

June 2009

\section{ABSTRACT \\ Parental Education and Wages: Evidence from China*}

Using nationally representative data in China, we find substantial positive partial correlations of both parents' education with one's wage. In addition, returns to father's education are higher in more monopsonistic and less meritocratic labor markets, including non-coastal regions, the state-owned sector, and the early periods of the reform era. The opposite is, however, true with respect to mother's education. Overall, the empirical evidence is consistent with the story that father's education mainly indicates family connections useful for locating a better-paying first job, while mother's education primarily captures unmeasured ability.

JEL Classification: J30, J62

Keywords: parental education, wages, family connections, unmeasured ability

Corresponding author:

Shuaizhang Feng

411A Robertson Hall

Woodrow Wilson School

Princeton University

Princeton, NJ 08544

USA

E-mail: shuaizha@princeton.edu

\footnotetext{
* We thank Peter Gottschalk, Bruce Meyer, and seminar participants at UC Davis, the 2008 Hong Kong Economics Association Biannual Conference and the 2008 International Symposium on Labor Economics in Xiamen for their comments and suggestions. We gratefully acknowledge financial support from Shanghai Pujiang Program for this work. All remaining errors are our own.
} 


\section{Introduction}

In the vast empirical literature of earnings determination, researchers typically find the education level of one's father or mother to be positive and significant when included (see literature review in the next section). Therefore, parental education either serves as a proxy for children's unobserved human capital, or represents something unrelated to productivity, but nonetheless rewarded in the labor market, such as labor market nepotism (Lam and Schoeni, 1993, 1994; Kramarz and Skans, 2007). To date, the existing literature as a whole has not paid enough attention to differentiating the two possible channels. Nevertheless, it is important to do so both to understand how labor market works in general and how human capital and earnings are transmitted across generations in particular (Piketty, 1998; Solon, 1999; Bowles and Gintis, 2002; and Nathan and Mulligan, 2002, Becker and Tomes, 1979, 1986).

In this paper, we analyze the relationship between parents' education and children’s wages using data from China. The Chinese society is traditionally paternalistic, thus one might expect parental characteristics to affect children's outcomes strongly. Furthermore, Chinese labor markets have experienced tremendous changes during the last several decades, moving from a fragmented, rigid system to market-based wage-setting institutions with increased labor mobility. In addition, developments across different geographic regions and employment sectors remain imbalanced. Thus, China's recent experience presents rich variations upon which to compare the impacts of parental education on children's wages.

Our empirical work is based upon two nationally representative data sets: the 2007 
supplement of Urban Household Survey from the National Bureau of Statistics (NBS) and the 2002 wave of China Household Income Project (CHIP). We find substantial positive partial correlations of parental education with one's wages. In addition, returns to father's education are higher in more monopsonistic and less meritocratic labor markets, including non-coastal regions, the state sector, and early periods of the reform era. In contrast, wage returns to mother’s education are higher in more developed labor markets.

Using a simple model of earnings generation, we interpret our results as suggesting quite different roles for mother's and father's schooling - while mother's education primarily serves as a proxy for unmeasured ability ${ }^{1}$, father's education stands for family connections useful in finding a good first job. This interpretation is consistent with the broad literature of child development and the pervasive role of family connections in the Chinese society $^{2}$. As fathers are usually the "heads" of families who determine the families' social economic status, paternal characteristics are more correlated with labor market nepotism than maternal ones. On the other hand, mothers' educations are probably more correlated with children's ability than fathers', as mothers typically play a more important role in parenting and spend more time with their children ${ }^{3}$.

1 For example, Altonji and Dunn (1996) show that mothers' education is positively correlated with children's return to education but father's education is not.

2 See Bian (1994), Zhang and Li (2003), and Knight and Yueh (2008) for studies on the role of social connection, or "guanxi", in Chinese society and economy.

3 The literature in general finds a strong effect of parental time with children on child development (see Leibowitz, 1977; Datcher-loury, 1988; and Ruhm, forthcoming). Price (2008) shows that fathers spend considerably less amount of quality time with their children. than mothers do, using American Time Use Survey data. Smith (1989) concludes that mothers and fathers influence their children's academic performance and educational goals through different mechanisms. Paternal influence is largely dependent upon father's 
The rest of the paper is structured as follows. The next section reviews the related literature. Section three provides a brief background introduction of institutional changes in China during the past several decades. Section four develops testable hypotheses based on a model of earnings generation. Section five describes the data sets. This is followed by empirical results in section six. The last section concludes with a comparison of our theoretical predictions with empirical findings.

\section{Literature Review}

Many Mincer-type regressions of earnings function include some parental characteristics such as their levels of education (Schultz, 1988). However, most of the times, it is motivated by concerns over the possible omitted variable bias on estimates of returns to schooling $^{4}$, rather than interests in parental-children relationship itself. Those studies usually find parental education to be positively associated with one's wages even controlling for other factors such as the schooling level of herself.

In the United States, Featherman and Houser (1978) find that family background variables have an important effect on early earnings but that such effects weaken over the life cycle, while Leibowitz (1974) presents evidence on the relative importance of mother's education on the earnings of sons. Heckman and Hotz (1986) examine determinants of wages for Panamanian males and find mother's education tends to have a persistently stronger and

providing financial support and encouragements, while maternal influence stems from role modeling for children.

4 This is especially the case for developing countries as the estimated returns to schooling are usually high. One might reasonable suspect that omitted variables bias might be larger in less developed economies as liquidity constraints and family background are likely to be important determinants of both education and earnings (Lam and Schoeni, 1993). 
more robust effect on earnings than father's education. Strauss and Thomas (1996) and Lam and Schoeni (1993) find large effects of parental education on the labor earnings of males in Brazil. Strauss and Thomas also show that family background is important for female wages. Liu, Hammitt and Lin (2000) estimate a wage equation for Taiwanese and find that the effect of father's schooling on wages is larger than the effect of mother's schooling - a university-educated father is associated with a $15 \%$ wage advantage compared with an illiterate father in the private sector. Li and Luo (2004) study the case of China and find that father's education is significant in affecting children's wages but mother's education is not significant.

In general, the literature has not paid enough attention towards interpreting the partial effects of parental education on one's wages. Most studies do not even attempt to understand these effects, while the few that do cannot offer a definitive answer. For example, Liu, Hammitt and Lin (2000) find that the effect of family background are significant in the private sector but not in the public sector. They attribute such effects to either family connections or unobserved ability, but are not able to differentiate the two.

A notable exception is the work by Lam and Schoeni (1993, 1994) ${ }^{5}$, which finds that a Brazilian man's earnings appear to be more strongly influenced by the schooling of his father-in-law than his own father. Based on a model of assortative mating and intergenerational transmission of schooling and earnings, they interpret the result as evidence that parental characteristics are more likely to be serving as proxies for

5 Agnarsson and Carlin (2002) conduct similar analysis in Sweden and find similar results. 
unobservable worker characteristics rather than as indicators of returns to nepotistic family connections in the labor market.

\section{Institutional Backgrounds}

The Chinese labor market has gone through tremendous changes in the last several decades. During the pre-reform period (1949-1977), due to the restrictions of the residential registration system ("hukou”), labor flows between rural and urban areas and among different geographical regions were insignificant. The government guarantees almost full employment in the urban areas, primarily through State-Owned-Enterprises (SOEs). Within a firm, wage differences were small and mainly determined by job positions and seniority. Due to the rigidity of the labor allocation system and the power held by authorities, family connections (or "guanxi”) are important in getting a good job that pays higher wages and better fringe benefits (Bian, 1994). There was also the prevalent practice of "jieban”, which entitled a retired worker's immediate family members, usually the son or daughter, the employment opportunity in the same factory or working unit.

As China started to open its door and implement market-oriented economic reform measures in the late 1970s, SOEs gained some freedom in their hiring decisions and were allowed to offer more flexible wages. Nevertheless, developments in SOEs lacked considerably the burgeoning non-state sectors, which include small proprietorships, township-and-village enterprises (TVEs), foreign and privately-owned businesses. Non-state firms are less likely to suffer from ambiguous property rights and agency problems as SOEs do, thus are more likely to pay their workers according to their marginal 
productivity. Consequently, returns to human capital are in general higher in the non-state sector (Zhao, 2002). Geographically, although all regions have achieved noticeable economic developments, the coastal regions as a whole have witnessed higher GDP growth rates especially after 1992 when the former leader Deng Xiaoping toured the South of the country. At about the same time, the central government has established several Special Economic Zones in coastal areas, with more favorable reform policies in terms of attracting foreign direct investments and promoting international trade. Overall, the coastal region has established more vibrant and competitive labor markets due to both preferential policies and geographic advantages (See: Wan, 2007; Benjamin et al., 2008; Fleisher and Chen; 1997; and Yang, 2002). In general, while "guanxi", or family connections, is still a pervasive feature of the Chinese society, its importance in the labor market diminished, especially in more competitive segments of the economy ${ }^{6}$.

\section{Model and Hypotheses}

In this section, we provide a theoretical framework similar to that in Lam and Schoeni (1994) and develop several hypotheses under different assumptions. We will use the empirical findings to examine the validity of these hypotheses in the last section of the paper.

To start, let the log wage for individual $\mathrm{i}$ at time $\mathrm{t}$ be denoted as $\mathrm{Y}_{\mathrm{it}}$. Suppose we observe wages at two time periods: $t=0$ when he enters the labor market (first job) and $t=1$ when the survey is administered (current job). We have

6 Démurger, Fournier, Li and Zhong (2006) provide a detailed summary of urban labor market reforms since 1978. 


$$
Y_{i 1}=\beta_{01}+\beta_{11} S C H_{i}+\beta_{21} A_{i}+\beta_{4} Y_{i 0}+\varepsilon_{i 1}
$$

In the above equations, $\mathrm{SCH}_{\mathrm{i}}$ is person i's years of schooling, $\mathrm{A}_{\mathrm{i}}$, which we loosely refer to as "ability”, represents all dimensions of human capital not captured by formal schooling, including one's innate ability. $\mathrm{J}_{\mathrm{i}}$ captures the wage effect of the first job search, and $\varepsilon_{i t}$ is the error term that represents all other idiosyncratic shocks ${ }^{7}$. Current wage reflects not only effects of education and ability, but also the effects of wages on the first job. Even if an individual has changed jobs, $\beta_{4}$ could still be positive as the previous wage serves as a benchmark when one conducts further job search (Burdett and Mortensen, 1998). Nevertheless, it is reasonable to expect the effects to be stronger when the worker stays at the same job.

The following two equations represent orthogonal decompositions of ability and job search on one’s education and her parents’ education.

(3) $A_{i}=\alpha_{a}+\gamma_{a} S C H_{i}+\gamma_{a f} F_{-} S C H_{i}+\gamma_{a m} M_{-} S C H_{i}+A_{i}^{u}$

(4) $J_{i}=\alpha_{j}+\gamma_{j f} F_{-} S C H_{i}+\gamma_{j m} M_{-} S C H_{i}+J_{i}^{u}$

Where $\mathrm{F}_{-} \mathrm{SCH}_{\mathrm{i}}$ and $\mathrm{M} \_\mathrm{SCH} \mathrm{H}_{\mathrm{i}}$ are father's and mother's years of schooling, respectively. $A_{i}^{u}$ and $J_{i}^{u}$ are orthogonal residue portions of ability and job search, respectively. The two equations implicitly assume that schooling is conditionally orthogonal to search on the first

7 Note that we do not include explicitly a job search term for current wage in equation (2). This is because current job search reflects more about one's own ability and education rather than effects of parents, which are the focus of our study. Here, we assume that current job search is correlated with ability but not education, so it is then subsumed in the error term of the ability equation (3). 
job, but not ability.

Substituting (3) and (4) into the wage equations, we have the following reduced form equations:

(5) $Y_{i 0}=\left(\beta_{00}+\beta_{20} \alpha_{a}+\beta_{3} \alpha_{j}\right)+\left(\beta_{10}+\beta_{20} \gamma_{a}\right) S C H_{i}+\left(\beta_{20} \gamma_{a f}+\beta_{3} \gamma_{j f}\right) F_{-} S C H_{i}+$

$\left(\beta_{20} \gamma_{a m}+\beta_{3} \gamma_{j m}\right) M_{-} S C H_{i}+\left(\beta_{20} A_{i}^{u}+\beta_{3} J_{i}^{u}+\varepsilon_{i 0}\right)$, and

(6) $Y_{i 1}=\left(\beta_{01}+\beta_{4} \beta_{00}+\beta_{4} \beta_{20} \alpha_{a}+\beta_{4} \beta_{3} \alpha_{j}+\beta_{21} \alpha_{a}\right)+$

$\left(\beta_{11}+\beta_{21} \gamma_{a}+\beta_{4} \beta_{10}+\beta_{4} \beta_{20} \gamma_{a}\right) S C H_{i}+\left(\beta_{4} \beta_{20} \gamma_{a f}+\beta_{4} \beta_{3} \gamma_{j f}+\beta_{21} \gamma_{a f}\right) F_{-} S C H_{i}+$

$\left(\beta_{4} \beta_{20} \gamma_{a m}+\beta_{4} \beta_{3} \gamma_{j m}+\beta_{21} \gamma_{a m}\right) M_{-} S C H_{i}+\left(\beta_{4} \beta_{20} A_{i}^{u}+\beta_{21} A_{i}^{u}+\beta_{4} \beta_{3} J_{i}^{u}+\beta_{4} \varepsilon_{i 0}+\varepsilon_{i 1}\right)$,

upon which we develop the comparative statics results:

Hypothesis H1: In labor markets that value human capital more (with larger $\beta_{10}, \beta_{11}, \beta_{20}$ and $\beta_{21}$, both coefficients on SCH for the first job and for the current job will be larger.

Assumption A1: $\gamma_{\mathrm{af}}<\gamma_{\mathrm{am}}$ and $\gamma_{\mathrm{jf}}>\gamma_{\mathrm{jm}}$, i.e., father's education is less correlated with children's ability and more correlated with first job search than mother's education.

Hypothesis H2: Under assumption A1, for both first job wage and current job wage, in labor markets that value human capital more (which has larger $\beta_{20}$ and $\beta_{21}$ ) and/or are less monopsonistic (which has smaller $\beta_{3}$ ), the difference between the coefficients on F_SCH and M_SCH will decrease (becomes more negative). This is obvious as for first job wage the difference in coefficients is $\beta_{3}\left(\gamma_{j f}-\gamma_{j m}\right)-\beta_{20}\left(\gamma_{a m}-\gamma_{a f}\right)$ and for the current wage the difference is $\beta_{4} \beta_{3}\left(\gamma_{j f}-\gamma_{j m}\right)-\left(\beta_{4} \beta_{20}+\beta_{21}\right)\left(\gamma_{a m}-\gamma_{a f}\right)$.

Hypothesis H3: (1) Under assumption A1, for current wage, it is ambiguous whether the difference between the coefficients on F_SCH and M_SCH will be smaller or larger for 
those who has changed jobs (hence has a smaller value of $\beta_{4}$ ) compared to those who never changed jobs. (2) Nevertheless, in labor markets in which first job search is considerably more important than ability ( $\beta_{3}$ sufficiently larger than $\beta_{20}$ ), the difference will be smaller (more negative).

Assumption A2: $\gamma_{\mathrm{af}} \ll \gamma_{\mathrm{jf}}$, i.e, father's education is (conditionally) sufficiently more correlated with initial job search than with ability.

Hypothesis H4: Under assumption A2, the coefficient on F_SCH will be smaller in labor markets that value human capital more (which has larger $\beta_{20}$ and $\beta_{21}$ ) and/or are less monopsonistic (which has smaller $\beta_{3}$ ).

Assumption A3: $\gamma_{\mathrm{am}} \gg \gamma_{\mathrm{jm}}$, i.e, mother's education is (conditionally) sufficiently more correlated with ability than initial job search.

Hypothesis H5: Under assumption A3, the coefficient on M_SCH will be larger in labor markets that value human capital more (which has larger $\beta_{20}$ and $\beta_{21}$ ) and/or are less monopsonistic (which has smaller $\beta_{3}$ ).

\section{Data and Sample Statistics}

Our main data source is the 2007 China Urban Household Supplemental Survey on Education from the National Bureau of Statistics (NBS) ${ }^{8}$. It is conducted by the urban survey department of NBS, and is based on the same sampling frames of the regular annual Urban Household Survey, to which the research community had limited access ${ }^{9}$. The

8 The data can be obtained from the Urban Survey Department, China National Bureau of Statistics.

9 Only data from six provinces in the Urban Household Survey has been available to the research community, see Zhang et al. (2005) and Zhang et al. (2008). 
supplement survey is representative of the nation's urban population, and includes 5,090 sampled households in twenty-one provinces ${ }^{10}$. Detailed questions about one's own education, her parents' education, and job-related information are asked in this supplement.

We first match the supplemental survey to the regular urban household survey, which contains basic household and individual demographic information. The supplemental survey only collects detailed job history information about one person in a household - the head if he or she is employed, otherwise the individual with the highest earnings in the household. Matching is not straightforward as the NBS only provides common household identifiers but not individual identifiers across the two surveys. Using the information on household heads' employment status, monthly income and other demographic information, we were able to match successfully 5,028 individuals. We further restrict the sample to workers with at most 32 years of experience by 2007, which corresponds to the cohort who started working after 1975 when the Cultural Revolution ended and the Chinese economy came back to normal track. We also exclude those with only primary education or less, as we will use the type of middle schools attended and performances in middle schools as control variables. In the last step we drop all females in the sample, as they are more likely to be self-selected as household heads, thus do not represent the female population in general. The resulting sample size is 3,153.

The NBS data is unique in that it asks questions for multiple jobs: current job,

10 There are 31 provinces (including municipalities and autonomous regions) in mainland China. The 21 provinces included in the survey are: Tianjin, Shanxi, Liaoning, Jilin, Heilongjiang, Shanghai, Jiangsu, Zhejiang, Fujian, Jiangxi, Shandong, Henan, Hubei, Hunan, Guangdong, Chongqing, Guizhou, Shangxi, Qinghai, Ningxia and Xinjiang. 
previous job, and the first job. All sample individuals report wages on current job if they are employed. Those who have ever changed jobs also report wages on the immediate previous job. If the previous job is not the first job ever hold, she also answers questions about the first job. In this paper, we transform all wages to constant 2006 RMB values, and create two separate samples in order to run two wage regressions ${ }^{11}$. Detailed procedures for constructing these variables are included in the appendix of the paper.

Summary statistics for the NBS current job sample are shown in Panel A of Table 1. Sample individuals on average have 11.4 years of schooling, and 18.5 years of work experience. The average number of years of schooling for fathers and mothers are 8.4 and 6.2 years, respectively. $23 \%$ of the individuals attended a key middle school ${ }^{12}$, and $43 \%$ self-reported that they either performed "very good” or "good” in middle school.

Sample size for the NBS first job sample is 676 (Panel B of Table 1), which is considerably less than the current job sample. Not surprisingly, the education variables all have similar values to those in the current job sample. Mean log wage rate is only 0.81 , which is substantially less than for the current job, reflecting the phenomenal real wage growths in the past several decades in China. 32\% of the sample reports graduating from high school in the coast regions.

Our second data source is the Chinese Household Income Project (CHIP) 2002

11 Suppose a person has held only one job, then we only have one wage observation which is the current wage. The survey does not ask the wages earned when the person first started the job.

12 Compared to other middle schools, a "key" school in China usually has better facilities and teachers, and admits better students on average. 
urban survey ${ }^{13}$. The CHIP dataset is also nationally representative and has been widely used in the literature as it is more accessible to the research community compared to NBS datasets (Li and Luo, 2004; Fleisher et. al., 2004). It includes 6,835 households and contains personal employment and wage information ${ }^{14}$. One advantage of the CHIP data is that it has the employer's ownership status (state owned, private owned or foreign owned, etc.), which allow us to examine whether returns to one's education and her parents' education differ by firm ownership.

We start with household heads and their spouses in the CHIP data as questions about parental education are only directly asked for those people. To make the sample comparable to the NBS data, we drop all females and only include those with at least some secondary education, and aged between 22 to 52 years old ${ }^{15}$. The resulting sample has 1,159 men, and the summary statistics are shown in Panel C of Table 1. Note that log real hourly wage is only 1.7 , which is much lower than 1.98 in the NBS current job sample. This is because CHIP wage is for the year 2002, while NBS current job wages are for the year 2007. The implied rate of annual increase for wage rate is about 7\%. The CHIP sample also has lower levels of parental education as they represent an older cohort than the NBS sample, but it shows a slightly higher level of average own schooling. We are not sure why these discrepancies arise but it is likely that NBS and CHIP have systematic differences in term of survey designs and/or data collection. Thus it is only prudent to use both and show that 13 Data downloaded through ICPSR, website: http://www.icpsr.umich.edu/cocoon/ICPSR/STUDY/21741.xml. 14 See Khan and Riskin (2005) for a detailed description of the data. 15 Our main results are robust to alternative age range restrictions. 
results are robust.

\section{Main Results}

\subsection{NBS Current Job and CHIP samples}

Table 2 presents OLS results of the wage regressions on current jobs based on the NBS and CHIP samples. The dependent variable in the regressions is log hourly wage rate on current job, and the explanatory variables include one's education (SCH), parental education (F_SCH and M_SCH), work experience (EXP) and its square divided by 100 (EXP2), self-rated performance in middle school (RANK), a dummy indicating whether attended a key middle school or not (SQ), the interaction term of RANK and SQ, city and

industry dummies. ${ }^{16}$ The first three columns of Table 2 report results using the NBS current job sample and the last three columns show the CHIP sample estimates.

Baseline Results

Columns (1) and (4) show the baseline results in the NBS Current Job and CHIP sample, respectively. Based on the NBS Current Job sample, wage return to one more year of schooling is $6.1 \%$, controlling for city and industry effects. The wage-experience profile shows a normal inverted U-shape, with wages increasing by around $10 \%$ in the first six years after labor market entry and reach the maximum at 18 years of general experience. These estimates are broadly in line with other findings in the literature. For example, Yang (2005) estimates returns to schooling of 3.1\% and 5.1\% in 1988 and 1995, respectively, using CHIP data. Zhang et al. (2005) estimate returns to education to be $7.5 \%$ for urban

16 Regression results not including city and industry dummies, available upon request from the authors, are similar to what was reported in this paper. 
males in 2001 based on NBS data.

Schooling levels of both parents are positively correlated with their son's wage. One additional year of father's education increases son's wage by $1.1 \%$, which is statistically significant at the $1 \%$ level. To put the number in perspective, comparing two otherwise identical individuals with one's father college-educated (16 years of schooling) and the other's father illiterate (zero years of schooling), the son of the college-educated father enjoys a $17.6 \%$ wage advantage - almost equal to the returns to three years' additional schooling on his own. In contrast, return to mother's education is statistically insignificant.

Compared with the NBS dataset, the CHIP data show a lower return to one's education at $4.7 \%$ as shown in Column (4). Considering that individuals in both samples are on average 41 years old and the CHIP data was collected about 5 years before the NBS data, the lower returns to education suggest that returns to schooling has increased for the younger cohort, which is consistent with the literature. Returns to father's education and mother's education are $0.4 \%$ and $0.3 \%$, respectively. Thus, although the return to mother's education was similar in CHIP and NBS datasets, wage return to father's schooling is much lower in CHIP.

\section{Job Changers vs. Stayers}

In column (2) of Table 2, we include a dummy indicating whether one has changed job or not and its interactions with the schooling variables. Compared to those who never changed job, those who did on average suffer a wage penalty of about $17 \%$. Noticeably, returns to father's education are quite different for stayers and changers. Wages are higher 
by $1.5 \%$ for each additional year of father's schooling if the individual never changed job, which is also statistically significant at $1 \%$ level, but only $0.4 \%$ for those who has switched jobs. Clearly, job changes are endogenous. But given that return to father's education is only substantial for those who never change jobs, it is possible that father's education affect one’s wage on current job primarily through his first job.

State vs. Non-state Sectors

Column (5) of Table 2 presents results that interact a State-Owned-Enterprises (SOEs) dummy and the education variables, using the CHIP sample. Workers in SOEs enjoy a $48 \%$ wage premium over their counterparts in non-state sectors. However, return to schooling is substantially lower in SOEs than in the non-state sector, with a difference of 3.7\%, which is significant at the $1 \%$ level (Similar findings are also reported by Zhao, 2002). In addition, return to father's education is $2.0 \%$ higher in the state sector than in the non-state sector, while return to mother's education is $1.7 \%$ lower. Both of these differences are statistically significant.

Coast vs. Non-coast Regions

We then interact a coast dummy with education variables and report the results in columns (3) and (6), using NBS and CHIP samples, respectively ${ }^{17}$. The results from both datasets show similar patterns. Average wage and return to one's schooling are higher in the more developed coastal areas than in non-coast provinces. In the NBS sample, return to father's education is significantly lower by $1.6 \%$ in the coast regions; the same sign is

17 In the NBS sample, coast provinces include Fujian, Guangdong, Jiangsu, Shandong, Shanghai, Tianjin and Zhejiang, In the CHIP sample, coast provinces include Beijing, Guangdong and Jiangsu. 
shown in the CHIP sample although not statistically significant. Return to mother's education is higher by $0.4 \%$ in coastal regions in both samples, but the difference is not statistically significant.

\subsection{NBS First Job Sample}

The results about those who have never changed job and those who have in the previous subsection suggest that the impact of father's education on wages may be one-shot which happen early in one's career. To explore this supposition in more detail, we analyze the NBS First Job sample. The results are shown in Table 3. Although we do not have first job wages for those who never changed job, and our analyses here are based on a self-selected sample, the comparative statics results should still hold.

\section{Baseline Results}

Columns (1) of Table 3 presents the regression results for the same models estimated in Table 2, except that the dependent variable now is one's wage on the first job. By definition, work experiences are all set to zero. As we don't know where individuals had their first job, only industry dummies are included. For one additional year of schooling, the wage of the first job increases by about $2.5 \%$. Thus return to schooling is substantially lower for the first job than for the current job as shown in Table 2. Schooling levels of both parents have a substantial effect on first job wage, with returns to father's and mother's education at $2.8 \%$ and $2.5 \%$, respectively.

\section{Coast vs. Non-coast Regions}

To examine how parental education affects wages on the first job in different 
markets, we compare coast with non-coast regions. Due to lack of information, we use the province where a person attended high school to proxy for the place where he had his first job. Biases from misclassification of coast/non-coast status are likely to be small, as only $3.7 \%$ of the sample has ever moved between non-coast and coast areas since high school graduation. Alternatively, we also tried to use current residency as a proxy for areas with the first job, and the results are almost the same.

Column (2) of Table 3 reports the results. Return to schooling is $6.0 \%$ higher in coastal areas than in non-coast areas, suggesting that coastal labor markets value human capital more. Interestingly, father's education has a significantly smaller impact on first job wages in coastal areas, by $5.5 \%$, than in non-coast areas. The difference is also statistically significant at $10 \%$ level. On the contrary, mother's education has a larger effect on first job wage in coastal areas, by $4.2 \%$, than in non-coast areas.

\section{Different Reform Periods}

NBS First Job sample also contains information about the year one started to work, allowing us to compare effects of parental education on different cohorts who started their first jobs in different time periods: the pre-reform era (before 1978), early-reform era (1978-1992), and the most recently period (post 1992) which corresponds to deepening of reform and open door policy.

We interact time dummies (the default group is the before-1978 period) with the education variables and present the results in columns (3) of Table 3. Consistent with other studies that report increasing returns to schooling in China (Fleisher et al., 2004, Zhang et 
al., 2005, and Yang, 2005), we find that return to education increased rapidly, especially after 1992. One additional year of schooling is only associated with less than $1 \%$ increase of wage before the 1990s, but raises one’s wage by $4.1 \%$ in the post-1992 period.

In addition, we observe that in terms of first job wages, return to father's education declines significantly over time, but return to mother's education shows a different pattern. In the pre-1978 period, return to father's education was as high as $15.2 \%$. It decreased to a meager $1.3 \%$ for the period between 1978 and 1992, as the economic reform took off, and declined further to $0.8 \%$ for the post-1992 period. On the other hand, return to mother's education increased from a negative but insignificant $-3.3 \%$ in the pre-1978 period to $2.6 \%$ in the 1978-1992 period, and then to $4 \%$ for the post-1992 period. The opposite movements of returns to father's and mother's education suggest that they must affect children's wages through quite different mechanisms.

\subsection{Robustness Checks}

Possible self-selection into different sectors or geographic regions

Strictly speaking, our comparative statics results hold only if workers are randomly assigned to different labor markets conditional on observables included in the regressions. This condition holds with respect to the time dimension, as the overall process of labor market liberalization is exogenous to individual behavior, and different cohorts of workers are subject to different labor markets. However, self-selection might contaminate our results in terms of comparisons between state and non-state sectors, as well as coast and non-coast regions. 
If workers self-select into state/non-state sectors or coast/non-coast regions based on some unobserved characteristics not related to parental education, then our OLS estimates are still consistent. Although a priori we have no reason to expect the interaction terms of parental education with these sector and region categories to be biased, we perform two stage least squares (2SLS) estimates as robustness checks as shown in Table 4. In general, these results are qualitatively similar to the OLS results and support our general hypotheses.

We use information on people’s migration history as instruments for coast/non-coast status. Column (1) of Table 4 presents IV results for the NBS Current Job sample. The corresponding OLS results are listed in column (3) of Table 2. Based on the IV estimates, return to schooling and return to mother's schooling are $7.2 \%$ and $2.4 \%$ higher in coastal areas than in non-coastal areas, but return to father's education is lower by $1.9 \%$. These estimates are of the same sign but slightly larger magnitudes than corresponding OLS estimates. Similarly, for CHIP sample IV results reported in column (3), return to father's education are lower by $7.9 \%$ in coastal areas, but returns to one’s own education and mother's education are both higher. Compared to the corresponding OLS results in column (6) of Table 2, the signs of these interaction terms are the same but the magnitudes are even larger using the IV method.

Column (2) of Table 4 report results that instrument state/non-state sector choice by whether jobs are assigned by government (which also includes "jieban”) using the CHIP sample. Not surprisingly, if one obtains his job through government or "jieban" practice, then he is much more likely to be in working in a state-owned-enterprise. Based on the IV 
estimates, return to schooling and return to mother's schooling are lower in the state sector by $8.1 \%$ and $3.5 \%$, respectively. However, return to father's schooling is higher by $3.9 \%$ in the state sector compared with non-state sector. These results again are consistent with the OLS results reported in column (5) of Table 2, with even more pronounced effects.

\section{Measurement Errors}

Schooling variables in both NBS and CHIP data unavoidably contain some measurement errors, especially when we convert degree categories to years of schooling for parents. Nevertheless, in most cases, measurement errors attenuate parameter estimates towards zero and inflate the estimated variance. Thus our parameter estimates would be even larger and statistically more significant if there were no measurement errors.

We also run median regressions which are more robust to outliers. The results are reported in Tables 5 and 6. Again these results are very close to the OLS results and suggest that our main findings are unlikely to be invalidated by possible data errors.

\section{Discussions and Conclusions}

Using NBS and CHIP data, we examine the partial correlations of parental education with adult children's wages in China. We find that although schooling levels of both parents are positively associated with children's wages, the effects change quite differently in different settings. The effect of father's education tends to be substantial only for those who never changed jobs, and is larger in earlier time periods, in non-coast areas and in the state sector. In contrast, mother's education has a larger effect in coast areas and in non-state sectors. 
We summarize our theoretical predictions from section three and empirical findings discussed in the previous section in table 7. The first three hypotheses (H1-H3) that are either derived from the model only, or used the additional assumption A1, have received very strong empirical support. Moreover, for hypothesis H4 that is based on much stronger assumptions A2, which states that father's education is sufficiently more correlated with initial job search than ability, the empirical evidence are also quite supportive. Hypothesis H5, which based on the assumption (A3) that mother's education is sufficiently more correlated with ability than first job search, has only receive mild support with most estimated coefficients not statistically significant.

Overall, our theoretical model and assumptions picture a consistent story - parental schoolings influence children's wages through very different mechanisms. While mother's education primarily captures unmeasured ability of children, father's education indicates family connections that help the children to find a better paying first job ${ }^{18}$.

In many wage regressions, parental levels of schooling are used as instrumental variables for one’s own education (For a recent example for China, see Giles, Park and Wang, 2008). Our study indicates that the biases from such IV estimators are likely to be context dependent and warrant careful interpretation. Similar to OLS estimates of return to education, IV estimates using either father’s or mother's education are likely to be upward biased. But a priori the magnitude of biases from different estimators are hard to tell. In particular, if one uses father's education as the IV, then the bias might be particularly large 18 Knight and Yueh (2008) provide direct evidence of social network on income for urban workers in China. 
for people who have just entered the labor market, especially in a developing country like China.

As a final note, we are not necessarily interpreting our results in a causal sense. Mothers of higher ability could both have more education themselves and produce (due to either heredity or better parenting) more able children who earn higher wages in labor market $^{19}$. Similarly, higher schooling of fathers does not translate directly into better first jobs for children. Future research should study the mechanisms of how fathers (or rather, the whole family) help with children to locate their first job. This will shed further light on issues such as intergenerational earnings mobility and labor market nepotism, especially in less developed countries.

19 Behrman and Rosenzweig (2002) and Plug (2004) argue that an increase in the schooling of mother's education would not have beneficial effects in terms of schooling of children. 


\section{References:}

Agnarsson, Sveinn and Carlin, Paul S. (2002), "Family Background and the Estimated Return to Schooling: Swedish Evidence”, Journal of Human Resources 37(3), 680-692.

Altonji , Joseph G. and Thomas A. Dunn (1996), “The Effects of Family Characteristics on the Return to Education”, Review of Economics and Statistics 78(4), 692-704.

Becker, Gary S.; Tomes, Nigel (1979), “An Equilibrium Theory of the Distribution of Income and Intergenerational Mobility”, Journal of Political Economy 87(6), 1153-1189.

Becker, Gary S.; Tomes, Nigel (1986), "Human Capital and the Rise and Fall of Families”, Journal of Labor Economics 4(3), 1-39.

Behrman, Jere R.; Rosenzweig, Mark R. (2002), “Does Increasing Women’s Schooling Raise the Schooling of the Next Generation?”, American Economic Review 92(1), 323-334.

Benjamin, Dwayne; Brandt, Loren; Giles, John; and Wang, Sangui (2008), “Income Inequality During China’s Economic Transition”, Chapter 18 in China's Great Economic Transformation, Loren Brandt and Thomas Rawski, editors. Cambridge University Press.

Bian, Yanjie (1994), “Guanxi and the Allocation of Urban Jobs in China”, China Quarterly 140, 971-999.

Bowles, Samuel and Herbert Gintis (2002), “The Inheritance of Inequality”, Journal of Economic Perspectives 16, 3-30.

Burdett, K. and D.T. Mortensen (1998), "Wage differentials, employer size, and unemployment", International Economic Review 39, 257-273. 
Datcher-Loury, Linda (1988), “Effects of Mother's Home Time on Children's Schooling”, Review of Economics and Statistics 70(3), 367-373.

Démurger, Sylvie, Martin Fournier, Shi Li and Wei Zhong (2006), “Economic Liberation with Rising Segmentation in China’s Urban Labor Market”, Asian Economic Papers 5(3), 58-101.

Featherman, D.; Hauser, R. (1978), Opportunity and Change. New York: Academic Press.

Fleisher, Belton M.; Chen, Jian (1997), “The Coast-Noncoast Income Gap, Productivity, and Regional Economic Policy in China”, Journal of Comparative Economics 25(2), 220-236.

Fleisher, Belton M.; Li, Haizheng; Li, Shi; Wang, Xiaojun (2004), "Sorting, Selection, and Transformation of the Return to College Education in China", IZA Discussion Paper No. 1446.

Nathan D. Grawe and Casey B. Mulligan (2002), "Economic Interpretations of Intergenerational Correlations”, Journal of Economic Perspectives 16(3), 45-58.

Heckman, J.J., \& Hotz, V.J. (1986). “An investigation of the labor market earnings of Panamanian males: evaluating the sources of inequality”, Journal of Human Resources 21(4), 507-542.

Giles, John; Park, Albert; and Wang, Meiyan, (2008), “The Great Proletarian Cultural Revolution, Disruptions to Education, and Returns to Schooling in Urban China”, World Bank Policy Research Working Paper No. 4729.

Khan, Azizur R., Riskin, Carl (2005), “China's household income and its distribution, 1995 
and 2002”, China Quarterly 182, 356-384.

Knight, John; Yueh, Linda (2008), “The role of social capital in the labour market in China”, Economics of Transition 16(3), 389-414.

Kramarz, Francis and Skans, Oskar N. (2007), "With a Little Help from my ... Parents ? Family Networks and Youth Labor Market Entry”, CEPR working paper.

Lam, David \& Schoeni, Robert F. (1993), "Effects of Family Background on Earnings and Returns to Schooling: Evidence from Brazil”, Journal of Political Economy 101(4), 710-40.

Lam, David \& Schoeni, Robert F. (1994), “Family Ties and Labor Markets in the United States and Brazil”, Journal of Human Resources 29(4), Special Issue: The Family and Intergenerational Relations, 1235-1258.

Leibowitz, Arleen (1977), “Parental Inputs and Children's Achievement”, Journal of Human Resources, Vol. 12, No. 2, 242-251.

Li, Haizheng and Yi Luo, (2004), "Reporting Errors, Ability Heterogeneity, and Returns to Schooling in China”, Pacific Economic Review 9(3), 191-207.

Liu, Jin-Tan; Hammitt, James K.; Lin, Chyongchiou Jeng (2000), “Family background and returns to schooling in Taiwan”, Economics of Education Review 19, 113-125.

Piketty, Thomas (1998), “Theories of Persistent Inequality and Intergenerational Mobility”, Chapter 6, Handbook of Income Distribution, edited by A. Atkinson and F. Bourguignon. Plug, Erik (2004), “Estimating the Effect of Mother’s Schooling on Children’s Schooling Using a Sample of Adoptees”, American Economic Review 94(1), 358-368. 
Price, Joseph (2008), “Parent-Child Quality Time: Does Birth Order Matter?” Journal of Human Resources 43(1): 240-265.

Ruhm, Christopher J. (forthcoming), “Maternal Employment and Child Development”, in D. Russell Crane and E. Jeffrey Hill (eds.) Handbook of Families and Work: Interdisciplinary Perspectives. University Press of America.

Schultz, T. Paul, (1988), “Education Investments and Returns”, in Handbook of Development Economics, ed. Hollis Chenery and T. N. Srinivasan, Volume 1, Chapter 13, 543-630. New York: North Holland.

Smith, Thomas Ewin (1989), “Mother-Father Differences in Parental Influence on School Grades and Educational Goals”, Sociological Inquiry 59(1), 88-98.

Solon, Gary (1999), “Intergenerational Mobility in the Labor Market”, Chapter 29, Handbook of Labor Economics v3, edited by Orley Ashenfelter and David Card.

Strauss, John; Thomas, Duncan (1996), “Wages, Schooling and Background: Investments in Men and Women in Urban Brazil”, Opportunity foregone: Education in Brazil, John Hopkins University Press.

Wan, Guanghua (2007), “Understanding Regional Poverty and Inequality Trends in China: Methodological Issues and Empirical Findings”, Review of Income and Wealth 53(1), 25-34.

Zhang, Junsen; Zhao, Yaohui; Park, Albert; Song, Xiaoqing (2005), “Economic Returns to Schooling in Urban China, 1988-2001”, Journal of Comparative Economics 33, 730-752. Zhang, Junsen; Han, Jun; Liu, Pak-wai; Zhao, Yaohui (2008), “Trends in the Gender 
Earnings Differential in Urban China, 1988-2004”, Industrial and Labor Relations Review 61(2), 224-243.

Zhang, Xiaobo; Li, Guo (2003), “Does Guanxi Matter to Nonfarm Employment”, Journal of Comparative Economics 31(2), 315-331.

Zhao, Yaohui (2002), “Earnings Differentials Between State and Non-state Enterprises in Urban China”, Pacific Economic Review 7(1), 181-197.

Yang, Dennis Tao (2005), “Determinants of Schooling Returns during Transition: Evidence from Chinese Cities”, Journal of Comparative Economics 33, 244-264.

Yang, Dennis Tao (2002), “What has caused regional inequality in China?”, China Economic Review 13(4), 331-334. 
Table 1: Variable Definitions and Summary Statistics

\begin{tabular}{|c|c|c|c|c|c|c|c|}
\hline \multirow[t]{2}{*}{ Variable Name } & \multirow[t]{2}{*}{ Variable Definition } & Mean & $\begin{array}{l}\text { Standard } \\
\text { Deviation }\end{array}$ & Mean & $\begin{array}{l}\text { Standard } \\
\text { Deviation }\end{array}$ & Mean & $\begin{array}{l}\text { Standard } \\
\text { Deviation }\end{array}$ \\
\hline & & \multicolumn{2}{|c|}{ NBS current job } & \multicolumn{2}{|c|}{ NBS first job } & \multicolumn{2}{|c|}{$\underline{\mathrm{CHIP}}$} \\
\hline LNW & Log hourly wage (in 2006 RMB) & 1.98 & 0.82 & 0.81 & 1.23 & 1.70 & 0.64 \\
\hline $\mathrm{SCH}$ & total years of schooling & 11.40 & 2.60 & 11.04 & 2.41 & 12.34 & 2.20 \\
\hline F_SCH & Father's total years of schooling & 8.37 & 4.23 & 7.81 & 4.19 & 7.85 & 4.40 \\
\hline M_SCH & Mother's total years of schooling & 6.24 & 4.50 & 5.61 & 4.31 & 5.13 & 4.46 \\
\hline EXP & Years of work experience & 18.49 & 7.68 & 20.61 & 6.52 & 18.24 & 5.58 \\
\hline RANK & $\begin{array}{l}\text { A dummy that equals } 1 \text { if self-reported performance is the middle school is very good or good, } \\
0 \text { otherwise }\end{array}$ & 0.43 & 0.50 & 0.40 & 0.49 & 0.54 & 0.50 \\
\hline SQ & A dummy that equals 1 if attend a key middel school, 0 otherwise. & 0.23 & 0.42 & 0.19 & 0.39 & 0.36 & 0.48 \\
\hline CHG_JOB & A dummy that equals 1 if the current job is not the first job, 0 otherwise. & 0.32 & 0.47 & & & & \\
\hline COAST & $\begin{array}{l}\text { A dummy that equals } 1 \text { if currently lives in a coastal province, or studied in a high school in the } \\
\text { coast area (in the NBS first job sample), } 0 \text { otherwise }\end{array}$ & 0.36 & 0.48 & 0.32 & 0.47 & 0.26 & 0.44 \\
\hline MIG_C & A dummy that equals 1 if migrate to current city from a coastal area, 0 otherwise & 0.06 & 0.24 & & & & \\
\hline MIG_NC & A dummy that equals 1 if migrate to current city from a noncoastal area, 0 otherwise & 0.21 & 0.40 & & & & \\
\hline T78-92 & A dummy that equals 1 if started first job between 1978 to 1992, 0 otherwise. & & & 0.70 & 0.46 & & \\
\hline POST-92 & A dummy that equals 1 if started first job after 1992, 0 otherwise. & & & 0.18 & 0.39 & & \\
\hline STATE & A dummy that equals 1 if working in a State-Owned-Enterprise, 0 otherwise & & & & & 0.63 & 0.48 \\
\hline JOB_ARR & $\begin{array}{l}\text { A dummy that equals } 1 \text { if the current job obtained through government arrangement or } \\
\text { retirement of parents, } 0 \text { otherwise }\end{array}$ & & & & & 0.59 & 0.49 \\
\hline MIG & A dummy that equals 1 if individual migrated to current residential city, 0 otherwise & & & & & 0.23 & 0.42 \\
\hline MIG_YR & Number of years since migrating to current city & & & & & 5.25 & 10.18 \\
\hline
\end{tabular}

Note: Sample sizes for the NBS current job, NBS first job, and CHIP samples are 3153, 676, and 1159, respectively. 
Table 2: OLS Wage Regressions, NBS Current Job and CHIP.

\begin{tabular}{|c|c|c|c|c|c|c|}
\hline & (1) & (2) & (3) & (4) & (5) & (6) \\
\hline & \multicolumn{3}{|c|}{ NBS current job } & \multicolumn{3}{|c|}{$\underline{\mathrm{CHIP}}$} \\
\hline \multirow[t]{2}{*}{$\mathrm{SCH}$} & $0.061 * * *$ & $0.058 * * *$ & $0.052^{* * *}$ & $0.047 * * *$ & $0.070^{* * *}$ & $0.045^{* * *}$ \\
\hline & $(0.006)$ & $(0.007)$ & $(0.008)$ & $(0.008)$ & $(0.012)$ & $(0.010)$ \\
\hline \multirow[t]{2}{*}{ F_SCH } & $0.011 * * *$ & $0.015 * * *$ & $0.014^{* * *}$ & 0.004 & -0.010 & 0.000 \\
\hline & $(0.004)$ & $(0.004)$ & $(0.005)$ & $(0.005)$ & $(0.008)$ & $(0.006)$ \\
\hline \multirow[t]{2}{*}{ M_SCH } & 0.003 & 0.000 & 0.001 & 0.003 & $0.015^{*}$ & $0.011^{*}$ \\
\hline & $(0.004)$ & $(0.004)$ & $(0.005)$ & $(0.005)$ & $(0.009)$ & $(0.006)$ \\
\hline \multirow[t]{2}{*}{ EXP } & $0.019 * * *$ & $0.024 * * *$ & $0.021^{* * *}$ & 0.009 & 0.008 & 0.013 \\
\hline & $(0.007)$ & $(0.007)$ & $(0.007)$ & $(0.014)$ & $(0.014)$ & $(0.015)$ \\
\hline \multirow[t]{2}{*}{ EXP2 } & $-0.054 * * *$ & $-0.061 * * *$ & $-0.051 * *$ & -0.015 & -0.015 & -0.013 \\
\hline & $(0.020)$ & $(0.020)$ & $(0.020)$ & $(0.041)$ & $(0.041)$ & $(0.044)$ \\
\hline \multirow[t]{2}{*}{ SCH*CHG_JOB } & & 0.006 & & & & \\
\hline & & $(0.011)$ & & & & \\
\hline \multirow[t]{2}{*}{ F_SCH*CHG_JOB } & & -0.011 & & & & \\
\hline & & $(0.008)$ & & & & \\
\hline \multirow[t]{2}{*}{ M_SCH*CHG_JOB } & & 0.007 & & & & \\
\hline & & $(0.007)$ & & & & \\
\hline \multirow[t]{2}{*}{ CHG_JOB } & & -0.171 & & & & \\
\hline & & $(0.127)$ & & & & \\
\hline \multirow[t]{2}{*}{ SCH*STATE } & & & & & $-0.037 * *$ & \\
\hline & & & & & $(0.015)$ & \\
\hline \multirow[t]{2}{*}{ F_SCH*STATE } & & & & & $0.020^{*}$ & \\
\hline & & & & & $(0.010)$ & \\
\hline \multirow[t]{2}{*}{ M_SCH*STATE } & & & & & $-0.017^{*}$ & \\
\hline & & & & & $(0.010)$ & \\
\hline \multirow[t]{2}{*}{ STATE } & & & & & $0.475^{* *}$ & \\
\hline & & & & & $(0.191)$ & \\
\hline \multirow[t]{2}{*}{$\mathrm{SCH}^{*} \mathrm{COAST}$} & & & $0.048 * * *$ & & & 0.029 \\
\hline & & & $(0.010)$ & & & $(0.018)$ \\
\hline \multirow[t]{2}{*}{ F_SCH ${ }^{*} \mathrm{COAST}$} & & & $-0.016 * *$ & & & -0.001 \\
\hline & & & $(0.008)$ & & & $(0.012)$ \\
\hline \multirow[t]{2}{*}{ M_SCH*COAST } & & & 0.004 & & & 0.004 \\
\hline & & & $(0.007)$ & & & $(0.012)$ \\
\hline \multirow[t]{2}{*}{ COAST } & & & 0.057 & & & 0.107 \\
\hline & & & $(0.122)$ & & & $(0.236)$ \\
\hline \multirow[t]{2}{*}{ Constant } & $1.283^{* * *}$ & $1.274 * * *$ & $1.047 * * *$ & 0.649 & 0.316 & $1.454 * * *$ \\
\hline & $(0.134)$ & $(0.139)$ & $(0.141)$ & $(0.527)$ & $(0.533)$ & $(0.226)$ \\
\hline Industry dummies & Yes & Yes & Yes & Yes & Yes & Yes \\
\hline City dummies & Yes & Yes & No & Yes & Yes & No \\
\hline Adjusted R-squared & 0.28 & 0.28 & 0.22 & 0.30 & 0.30 & 0.20 \\
\hline
\end{tabular}

Note: Dependent Variable is LNW. Other explanatory variables included are RANK, SQ and their interaction term. Robust standard errors are reported in parentheses. ${ }^{* * *}$ stands for statistical significance at the $1 \%$ level, ${ }^{* *}$ at $5 \%$ level, and * at $10 \%$ level. 
Table 3: OLS Wage Regressions, NBS First Job.

\begin{tabular}{|c|c|c|c|}
\hline & $(1)$ & $(2)$ & $(3)$ \\
\hline $\mathrm{SCH}$ & $\begin{array}{l}0.025 \\
(0.022)\end{array}$ & $\begin{array}{l}0.005 \\
(0.025)\end{array}$ & $\begin{array}{l}0.002 \\
(0.077)\end{array}$ \\
\hline F_SCH & $\begin{array}{l}0.028 * * \\
(0.013)\end{array}$ & $\begin{array}{l}0.042^{* * *} \\
(0.016)\end{array}$ & $\begin{array}{l}0.152^{* * *} \\
(0.043)\end{array}$ \\
\hline M_SCH & $\begin{array}{l}0.025^{*} \\
(0.013)\end{array}$ & $\begin{array}{l}0.01 \\
(0.016)\end{array}$ & $\begin{array}{l}-0.033 \\
(0.038)\end{array}$ \\
\hline $\mathrm{SCH}^{*} \mathrm{COAST}$ & & $\begin{array}{l}0.06 \\
(0.041)\end{array}$ & \\
\hline F_SCH $*$ COAST & & $\begin{array}{l}-0.055^{*} \\
(0.029)\end{array}$ & \\
\hline M_SCH*COAST & & $\begin{array}{l}0.042 \\
(0.028)\end{array}$ & \\
\hline COAST & & $\begin{array}{l}-0.223 \\
(0.452)\end{array}$ & \\
\hline SCH*T78-92 & & & $\begin{array}{l}0.003 \\
(0.081)\end{array}$ \\
\hline M_SCH*T78-92 & & & $\begin{array}{l}0.059 \\
(0.042)\end{array}$ \\
\hline F_SCH*T78-92 & & & $\begin{array}{l}-0.139 * * * \\
(0.046)\end{array}$ \\
\hline T78-92 & & & $\begin{array}{l}0.595 \\
(0.911)\end{array}$ \\
\hline SCH*POST-92 & & & $\begin{array}{l}0.039 \\
(0.084)\end{array}$ \\
\hline M_SCH*POST-92 & & & $\begin{array}{l}0.073 \\
(0.046)\end{array}$ \\
\hline F_SCH*POST-92 & & & $\begin{array}{l}-0.144^{* * *} \\
(0.050)\end{array}$ \\
\hline POST-92 & & & $\begin{array}{l}0.65 \\
(0.943)\end{array}$ \\
\hline Constant & $\begin{array}{l}-0.552^{*} \\
(0.304)\end{array}$ & $\begin{array}{l}-0.486 \\
(0.337)\end{array}$ & $\begin{array}{l}-0.852 \\
(0.881)\end{array}$ \\
\hline Industry dummies & Yes & Yes & Yes \\
\hline Adjusted R-squared & 0.09 & 0.1 & 0.12 \\
\hline
\end{tabular}

Note: Dependent Variable is LNW. Other explanatory variables included are EXP, EXP2, RANK, SQ and the interaction term of RANK and SQ. Robust standard errors are reported in parentheses. ${ }^{* * *}$ stands for statistical significance at the $1 \%$ level, ${ }^{* *}$ at $5 \%$ level, and $*$ at $10 \%$ level. 
Table 4: IV Wage Regressions

\begin{tabular}{|c|c|c|c|}
\hline & (1) & (2) & (3) \\
\hline & $\underline{\text { NBS current job }}$ & $\underline{\mathrm{CHIP}}$ & $\underline{\mathrm{CHIP}}$ \\
\hline \multicolumn{4}{|l|}{ Second stage regression } \\
\hline \multirow[t]{2}{*}{$\overline{\mathrm{SCH}}$} & $0.043 * * *$ & $0.111^{* * *}$ & 0.03 \\
\hline & $(0.013)$ & $(0.024)$ & $(0.021)$ \\
\hline \multirow[t]{2}{*}{ F_SCH } & $0.015^{*}$ & $-0.025^{*}$ & 0.019 \\
\hline & $(0.008)$ & $(0.015)$ & $(0.013)$ \\
\hline \multirow[t]{2}{*}{ M_SCH } & -0.009 & $0.037 * *$ & 0.001 \\
\hline & $(0.008)$ & $(0.015)$ & $(0.013)$ \\
\hline \multirow[t]{2}{*}{ SCH*STATE } & & $-0.081 * *$ & \\
\hline & & $(0.034)$ & \\
\hline \multirow[t]{2}{*}{ F_SCH*STATE } & & $0.039 *$ & \\
\hline & & $(0.021)$ & \\
\hline \multirow[t]{2}{*}{ M_SCH*STATE } & & $-0.035 *$ & \\
\hline & & $(0.021)$ & \\
\hline \multirow[t]{2}{*}{ STATE } & & $1.002 * *$ & \\
\hline & & $(0.428)$ & \\
\hline \multirow[t]{2}{*}{$\mathrm{SCH}^{*} \mathrm{COAST}$} & $0.072 * *$ & & 0.089 \\
\hline & $(0.031)$ & & $(0.068)$ \\
\hline \multirow[t]{2}{*}{ F_SCH*COAST } & -0.019 & & $-0.079 *$ \\
\hline & $(0.021)$ & & $(0.047)$ \\
\hline \multirow[t]{2}{*}{ M_SCH*COAST } & 0.024 & & 0.042 \\
\hline & $(0.020)$ & & $(0.046)$ \\
\hline \multirow[t]{2}{*}{ COAST } & -0.391 & & -0.278 \\
\hline & $(0.388)$ & & $(0.927)$ \\
\hline \multicolumn{4}{|l|}{ First stage regression } \\
\hline \multirow[t]{2}{*}{ JOB_ARR } & & $0.364 * * *$ & \\
\hline & & $(0.027)$ & \\
\hline \multirow[t]{2}{*}{ MIG } & & & $0.204^{* *}$ \\
\hline & & & $(0.090)$ \\
\hline \multirow[t]{2}{*}{ MIG_YR } & & & $-0.009 * *$ \\
\hline & & & $(0.004)$ \\
\hline \multirow[t]{2}{*}{ MIC_C } & $0.382^{* * *}$ & & \\
\hline & $(0.035)$ & & \\
\hline \multirow[t]{2}{*}{ MIC_NC } & $-0.252 * * *$ & & \\
\hline & $(0.020)$ & & \\
\hline \multirow{2}{*}{$\begin{array}{l}\text { F-stat for joint significance of all IVs } \\
\text { p-value }\end{array}$} & 158.7 & 184.2 & 3.4 \\
\hline & 0.000 & 0.000 & 0.035 \\
\hline
\end{tabular}

Note: Dependent Variable is LNW. Other explanatory variables included are EXP, EXP2, RANK, SQ and the interaction term of RANK and SQ. Robust standard errors are reported in parentheses. $* * *$ stands for statistical significance at the $1 \%$ level, $* *$ at $5 \%$ level, and $*$ at $10 \%$ level. 
Table 5: Median Wage Regressions, NBS Current Job and CHIP.

\begin{tabular}{|c|c|c|c|c|c|c|}
\hline & (1) & (2) & (3) & (4) & (5) & (6) \\
\hline & \multicolumn{3}{|c|}{ NBS current job } & \multicolumn{3}{|c|}{$\underline{\mathrm{CHIP}}$} \\
\hline \multirow[t]{2}{*}{$\mathrm{SCH}$} & $0.059 * * *$ & $0.054 * * *$ & $0.053 * * *$ & $0.047 * * *$ & $0.069 * * *$ & $0.044 * * *$ \\
\hline & $(0.006)$ & $(0.006)$ & $(0.007)$ & $(0.013)$ & $(0.015)$ & $(0.010)$ \\
\hline \multirow[t]{2}{*}{ F_SCH } & $0.008^{* *}$ & $0.009 * *$ & $0.014 * * *$ & -0.002 & -0.013 & -0.007 \\
\hline & $(0.004)$ & $(0.004)$ & $(0.004)$ & $(0.007)$ & $(0.009)$ & $(0.006)$ \\
\hline \multirow[t]{2}{*}{ M_SCH } & 0.006 & 0.002 & -0.002 & $0.016 * *$ & $0.038 * * *$ & $0.015^{* * *}$ \\
\hline & $(0.004)$ & $(0.004)$ & $(0.004)$ & $(0.007)$ & $(0.008)$ & $(0.006)$ \\
\hline \multirow[t]{2}{*}{ EXP } & $0.025^{* * *}$ & $0.032 * * *$ & $0.026 * * *$ & 0.026 & $0.033^{* *}$ & 0.017 \\
\hline & $(0.008)$ & $(0.006)$ & $(0.007)$ & $(0.022)$ & $(0.016)$ & $(0.015)$ \\
\hline \multirow[t]{2}{*}{ EXP2 } & $-0.065^{* * *}$ & $-0.076 * * *$ & $-0.063^{* * *}$ & -0.039 & -0.064 & -0.023 \\
\hline & $(0.021)$ & $(0.017)$ & $(0.019)$ & $(0.062)$ & $(0.047)$ & $(0.044)$ \\
\hline \multirow[t]{2}{*}{ SCH ${ }^{*}$ CHG_JOB } & & $0.020^{* *}$ & & & & \\
\hline & & $(0.009)$ & & & & \\
\hline \multirow[t]{2}{*}{ F_SCH*CHG_JOB } & & -0.004 & & & & \\
\hline & & $(0.007)$ & & & & \\
\hline \multirow[t]{2}{*}{ M_SCH*CHG_JOB } & & 0.008 & & & & \\
\hline & & $(0.006)$ & & & & \\
\hline \multirow[t]{2}{*}{ CHG_JOB } & & $-0.422 * * *$ & & & & \\
\hline & & $(0.107)$ & & & & \\
\hline \multirow[t]{2}{*}{ SCH*STATE } & & & & & $-0.035^{* *}$ & \\
\hline & & & & & $(0.018)$ & \\
\hline \multirow[t]{2}{*}{ F_SCH*STATE } & & & & & 0.014 & \\
\hline & & & & & $(0.011)$ & \\
\hline \multirow[t]{2}{*}{ M_SCH*STATE } & & & & & $-0.032 * * *$ & \\
\hline & & & & & $(0.011)$ & \\
\hline \multirow[t]{2}{*}{ STATE } & & & & & $0.652 * * *$ & \\
\hline & & & & & $(0.216)$ & \\
\hline \multirow[t]{2}{*}{$\mathrm{SCH}^{*} \mathrm{COAST}$} & & & $0.050 * * *$ & & & 0.015 \\
\hline & & & $(0.010)$ & & & $(0.019)$ \\
\hline \multirow[t]{2}{*}{ F_SCH*COAST } & & & $-0.020 * * *$ & & & 0.010 \\
\hline & & & $(0.008)$ & & & $(0.012)$ \\
\hline \multirow[t]{2}{*}{ M_SCH*COAST } & & & 0.006 & & & 0.006 \\
\hline & & & $(0.007)$ & & & $(0.011)$ \\
\hline \multirow[t]{2}{*}{ COAST } & & & -0.033 & & & 0.214 \\
\hline & & & $(0.116)$ & & & $(0.235)$ \\
\hline \multirow[t]{2}{*}{ Constant } & $1.328 * * *$ & $1.308 * * *$ & $1.176^{* * *}$ & $1.286^{* * * *}$ & $0.907 * * *$ & $1.529 * * *$ \\
\hline & $(0.150)$ & $(0.120)$ & $(0.133)$ & $(0.422)$ & $(0.345)$ & $(0.313)$ \\
\hline Industry dummies & Yes & Yes & Yes & Yes & Yes & Yes \\
\hline City dummies & Yes & Yes & No & Yes & Yes & No \\
\hline
\end{tabular}

Note: Same as in Table 2. 
Table 6: Median Wage Regressions, NBS First Job.

\begin{tabular}{|c|c|c|c|}
\hline & (1) & (2) & (3) \\
\hline \multirow[t]{2}{*}{$\mathrm{SCH}$} & 0.030 & -0.003 & -0.023 \\
\hline & $(0.036)$ & $(0.032)$ & $(0.092)$ \\
\hline \multirow[t]{2}{*}{ F_SCH } & 0.021 & 0.024 & $0.160^{* * *}$ \\
\hline & $(0.021)$ & $(0.019)$ & $(0.054)$ \\
\hline \multirow[t]{2}{*}{ M_SCH } & 0.026 & 0.014 & -0.011 \\
\hline & $(0.021)$ & $(0.019)$ & $(0.052)$ \\
\hline \multirow[t]{2}{*}{ SCH*COAST } & & 0.075 & \\
\hline & & $(0.054)$ & \\
\hline \multirow[t]{2}{*}{ F_SCH*COAST } & & -0.009 & \\
\hline & & $(0.037)$ & \\
\hline \multirow[t]{2}{*}{ M_SCH*COAST } & & 0.022 & \\
\hline & & $(0.036)$ & \\
\hline \multirow[t]{2}{*}{ COAST } & & -0.769 & \\
\hline & & $(0.580)$ & \\
\hline \multirow[t]{2}{*}{ SCH*T78-92 } & & & 0.037 \\
\hline & & & $(0.098)$ \\
\hline \multirow[t]{2}{*}{ M_SCH*T78-92 } & & & 0.046 \\
\hline & & & $(0.056)$ \\
\hline \multirow[t]{2}{*}{ F_SCH*T78-92 } & & & $-0.161 * * *$ \\
\hline & & & $(0.057)$ \\
\hline \multirow[t]{2}{*}{ T78-92 } & & & 0.663 \\
\hline & & & $(1.037)$ \\
\hline \multirow[t]{2}{*}{ SCH*POST-92 } & & & 0.111 \\
\hline & & & $(0.110)$ \\
\hline \multirow[t]{2}{*}{ M_SCH*POST-92 } & & & 0.019 \\
\hline & & & $(0.069)$ \\
\hline \multirow[t]{2}{*}{ F_SCH*POST-92 } & & & $-0.133 *$ \\
\hline & & & $(0.070)$ \\
\hline \multirow[t]{2}{*}{ POST-92 } & & & 0.153 \\
\hline & & & (1.181) \\
\hline \multirow[t]{2}{*}{ Constant } & -0.405 & -0.055 & -0.677 \\
\hline & $(0.461)$ & $(0.395)$ & $(0.995)$ \\
\hline Industry dummies & Yes & Yes & Yes \\
\hline
\end{tabular}

Note: Same as in Table 3. 
Table 7: Comparing Theoretical Predictions with Empirical Results

\begin{tabular}{|c|c|c|c|c|c|c|c|}
\hline \multicolumn{4}{|c|}{ Theoretical Predictions } & \multicolumn{4}{|c|}{ Empirical Results } \\
\hline Assumption & Hypothesis & Coefficient(s) & Comparison (predicted sign) & $\begin{array}{c}\text { OLS } \\
\text { Estimates }\end{array}$ & $\begin{array}{c}\text { IV } \\
\text { Estimates }\end{array}$ & $\begin{array}{c}\text { Median } \\
\text { Regression }\end{array}$ & Sample \\
\hline \multirow{6}{*}{ None } & \multirow{6}{*}{ H1 } & \multirow{6}{*}{ Coef(SCH) } & & $4.7 \%^{* * *}$ & $7.2 \% * *$ & $5.0 \% * * *$ & NBS current job \\
\hline & & & coast vs. non-coast $(+)$ & $2.9 \%$ & $8.9 \%$ & $1.5 \%$ & CHIP \\
\hline & & & & $6.0 \%$ & & $7.5 \%$ & NBS first job \\
\hline & & & $1978-1992$ vs. pre $1978(+)$ & $0.3 \%$ & & $3.7 \%$ & NBS first job \\
\hline & & & post 1992 vs. $1978-1992(+)$ & $3.6 \%$ & & $7.4 \%$ & NBS first job \\
\hline & & & non-state vs. state $(+)$ & $3.7 \% * *$ & $8.1 \% * *$ & $3.5 \%$ & CHIP \\
\hline \multirow{7}{*}{ A1 } & \multirow{6}{*}{$\mathrm{H} 2$} & \multirow{6}{*}{ Coef(F_SCH)-Coef(M_SCH) } & & $-1.2 \%$ & $-4.3 \%$ & $-2.6 \% * *$ & NBS current job \\
\hline & & & coast vs. non-coast (-) & $-0.5 \%$ & $-12.1 \%$ & $4.0 \%$ & CHIP \\
\hline & & & & $-9.7 \% * *$ & & $-2.9 \%$ & NBS first job \\
\hline & & & $1978-1992$ vs. pre $1978(-)$ & $-19.0 \% * * *$ & & $-20.7 \% * * *$ & NBS first job \\
\hline & & & post 1992 vs. $1978-1992(-)$ & $-3.0 \%$ & & $5.5 \%$ & NBS first job \\
\hline & & & non-state vs. state (-) & $-37.0 \% * *$ & $-7.4 \% * *$ & $-4.6 \% * * *$ & CHIP \\
\hline & H3 & Coef(F_SCH)-Coef(M_SCH) & $\begin{array}{l}\text { changed vs. never changed job } \\
\text { (ambiguous, possibly -) }\end{array}$ & $-1.8 \%$ & & $-1.2 \%$ & NBS current job \\
\hline \multirow{6}{*}{ A2 } & \multirow{6}{*}{$\mathrm{H} 4$} & \multirow{6}{*}{ Coef(F_SCH) } & & $-1.6 \% * *$ & $-1.9 \%$ & $-2.0 \% * * *$ & NBS current job \\
\hline & & & coast vs. non-coast (-) & $-5.5 \% *$ & $-7.9 \% *$ & $1.0 \%$ & CHIP \\
\hline & & & & $-0.1 \%$ & & $-0.9 \%$ & NBS first job \\
\hline & & & $1978-1992$ vs. pre $1978(-)$ & $-14.0 \% * * *$ & & $-16.1 \% * * *$ & NBS first job \\
\hline & & & post 1992 vs. $1978-1992(-)$ & $-0.5 \%$ & & $2.8 \%$ & NBS first job \\
\hline & & & non-state vs. state (-) & $-2.0 \% *$ & $-3.9 \% *$ & $-1.4 \%$ & CHIP \\
\hline \multirow{6}{*}{ A3 } & \multirow{6}{*}{ H5 } & \multirow{6}{*}{ Coef(M_SCH) } & & $0.4 \%$ & $2.4 \%$ & $0.6 \%$ & NBS current job \\
\hline & & & coast vs. non-coast $(+)$ & $4.2 \%$ & $4.2 \%$ & $0.6 \%$ & CHIP \\
\hline & & & & $0.4 \%$ & & $2.2 \%$ & NBS first job \\
\hline & & & $1978-1992$ vs. pre $1978(+)$ & $5.9 \%$ & & $4.6 \%$ & NBS first job \\
\hline & & & post 1992 vs. $1978-1992(+)$ & $1.4 \%$ & & $-2.7 \%$ & NBS first job \\
\hline & & & non-state vs. state $(+)$ & $1.7 \% *$ & $3.5 \% *$ & $3.2 \% * * *$ & CHIP \\
\hline
\end{tabular}


Note: Empirical results based on the same estimation results reported in Tables $2-6 .{ }^{* * *}$ stands for statistical significance at the $1 \%$ level, $* *$ at $5 \%$ level, and $*$ at $10 \%$ level. 
Appendix: Construction of Main Variables

Wages - In both NBS and CHIP, hourly wage rate is used as the dependent variable. We divide annual earnings (including regular wages, bonuses and other kinds of subsidies) by total hours worked in the year, where total hours worked equal the multiple of hours worked per day, days worked per week, and number of weeks worked in the year. Because NBS does not ask actual total number of weeks worked in the year, we assume it to be 50 for all employed individuals. Using annual earnings instead of hourly wage rates does not change our results qualitatively. To make wages comparable across time, we also deflate hourly wages using the urban consumption price index published by the National Bureau of Statistics. Price indices are obtained from various China statistical yearbooks and NBS publications. We also exclude the top and bottom one percent of the wages in the distribution to minimize the effect of outliers.

Work experience - We measure an individual's work experience in NBS by deduct the starting year of the first job from 2007, the year the survey is conducted. CHIP asks respondents to report their years of work experience directly.

Years of Schooling - Individual's years of schooling are directly reported in both datasets. However, schooling levels of fathers and mothers are reported as degree categories, but converted to years of schooling to be used in all our analyses. For example, we assign 16 years of schooling to those who have a college's degree.

Self-reported rank in middle school and school quality - Rank in school is reported in five categories: “very good”, “good”, “average”, "below average” and "bad”. We define the rank variable as a dummy that equals to 1 if the individual reports his performance to be either “very good” or "good”, 0 otherwise. Another dummy is constructed to indicate whether the person attended a key middle school or not. Both variables are used as controls of personal innate ability and quality of secondary education in the wage regressions. 